\title{
MICROBICIDE ACTIVITY OF CLOVE ESSENTIAL OIL (EUGENIA CARYOPHYLLATA)
}

\author{
L. Nuñez ${ }^{*}$, M. D’ Aquino
}

Hygiene, Faculty of Pharmacy and Biochemistry, University of Buenos Aires, Argentina.

Submitted: July 23, 2010; Returned to authors for corrections: November 08, 2011; Approved: June 07, 2012.

\begin{abstract}
Clove essential oil, used as an antiseptic in oral infections, inhibits Gram-negative and Gram-positive bacteria as well as yeast. The influence of clove essential oil concentration, temperature and organic matter, in the antimicrobial activity of clove essential oil, was studied in this paper, through the determination of bacterial death kinetics. Escherichia coli, Staphylococcus aureus and Pseudomonas aeruginosa were the microorganisms selected for a biological test. To determine the temperature effect, they were assayed at $21^{\circ}$ and $37^{\circ} \mathrm{C}$. The concentration coefficient was determined with $0.4 \%$, and $0.2 \%$ of essential oil. The influence of the presence of organic matter was determined with $0.4 \%$ of essential oil. The results obtained demonstrated that Escherichia coli were more sensitive even though the essential oil exerted a satisfactory action in three cases. In the three microbial species, $0.4 \%$ of essential oil at $21^{\circ} \mathrm{C}$ have reduced the bacterial population in 5 logarithmic orders. Organic matter reduces the antibacterial activity even though the bactericide efficacy was not lost. Clove essential oil can be considered as a potential antimicrobial agent for external use
\end{abstract}

Key words: clove essential oil; concentration coefficient; organic matter; antibacterial activity

\section{INTRODUCTION}

Essential oils are potential sources of novel antimicrobial compounds especially against bacterial pathogens (21). Edible, medicinal and herbal plants and spices such as oregano, rosemary, thyme, sage, basil, turmeric, ginger, garlic, nutmeg, clove, mace, savory and fennel have been successfully used either alone or in combination with other preservation methods (24). The antimicrobial property of essential oils from plants was used empirically for centuries, but only recently has it been studied scientifically. An increasingly body of research is being compiled on the antimicrobial activity of various plant oil extracts and their specific components for possible application in fields ranking from food industry to dentistry (3, $12,18)$.

Dormans and Deans (6) evaluated the antibacterial activity of six essential oils against 25 different genera of bacteria; all bacteria had a degree of sensitivity to essential oils tested. Oils with higher activity were thyme, oregano and cloves.

Clove oil has biological activities, such as antibacterial, antifungal, insecticidal and antioxidant properties, and is used traditionally as a savoring agent and antimicrobial material in food $(13,15,19)$. In addition, clove oil is used as an antiseptic in oral infections $(18,22)$. This essential oil has been reported to inhibit the growth of molds, yeasts and bacteria (17). It was

*Corresponding Author. Mailing address: Hygiene, Faculty of Pharmacy and Biochemistry. University of Buenos Aires. Argentina, Junin 956 - (1113 ) Buenos Aires Argentina.; Tel.: (54) 1149648257 Fax: (54) 114964 8274.; E-mail: lidian@ffyb.uba.ar 
effective against L. monocytogenes and $S$. Enteritidis in triptone Soya Broth and cheese (23). The high levels of eugenol contained in clove essential oil are responsible for its strong biological and antimicrobial activities. It is well know that both eugenol and clove essential oil phenolic compounds can denature proteins and react with cell membrane phospholipids changing their permeability and inhibiting a great number of Gram-negative and Gram-positive bacteria as well as different types of yeast $(4,26)$.

Microbial inactivation is a kinetic process in which viability of organisms exposed to biocide varies with time. The kinetics of inactivation depends on the type of microorganism, the type and concentration of biocide, and environmental conditions such as temperature, $\mathrm{pH}$ and presence of organic matter (27). Different chemicals presented as effective antimicrobial agents under ideal laboratory conditions often show significant loss of activity when exposed to organic agents such as serum, blood, proteins, etc (25).

Few studies have been conducted on the influence of these factors on the antimicrobial activity of clove essential oil. The aim of this work is to determine through death curves, the effect of concentration, temperature and organic matter on antimicrobial activity of this essential oil.

\section{MATERIALS AND METHODS}

\section{Antimicrobial compounds}

The clove essential oil (ECO) was provided by Fritzsche S. A. I. C. A. The ECO was dissolved in propylene glycol (PPG) $(50 \% \mathrm{v} / \mathrm{v})$.

This essential oil was chemically evaluated by gas chromatograph (GC). GC analysis was performed on a Varian Star gas chromatograph equipped with detector ADCB using a non-polar DB-5 fused silica capillary column (30 m x $0.25 \mathrm{~mm}$ i.d., $0.25 \mu \mathrm{m}$ film thickness); and total run time was $60 \mathrm{~min}$. The main composition of the essential oil used in this study, was: eugenol (83.13\%), $\beta$ caryophyllene $(6.88 \%), \alpha$ humulene $(2.48 \%)$, oxicaryophylene $(3.59 \%)$, eugenyl acetate $(2.41 \%)$.
Eugenol is primarily responsible for bacteriocidal/bacteriostatic properties $(24,26)$.

\section{Microorganisms}

Escherichia coli ATCC 25922; Staphylococcus aureus ATCC 6538 P; and Pseudomonas aeruginosa ATCC 27853 were used. Bacterial subcultures have been performed on tryptone soy agar (Oxoid), and suspended in 1\% peptonized water, to reach, approximately, $10^{9} \mathrm{cfu} / \mathrm{mL}$.

\section{Bacterial death kinetics}

Determination of bactericide effect was performed according Briozzo et al (1). Briefly, tubes containing $9.9 \mathrm{ml}$ of test solution were placed in a water bath at $21^{\circ} \mathrm{C}$ and $37^{\circ} \mathrm{C}$, and $0.1 \mathrm{ml}$ of bacterial suspension was added. Samples were withdrawn at $0,1,2,3,5,8,10$ minute intervals. After each period, the antimicrobial action was neutralized by means of a $1 / 10$ dilution in peptonized water with $3 \%$ Tween 80 and $0.07 \%$ soy lecithin for 10 minutes. All neutralized dilutions were surface-spread in petri dishes with tryptone soy agar with Tween-lecithin. Plates were incubated at $35^{\circ} \mathrm{C}$ for $48 \mathrm{~h}$.

When assays were carried out with organic matter, such matter was added to the disinfectant solution.

To determine the concentration coefficient $(\eta)$, we were working with $0.4 \%$ and $0.2 \%$ of disinfecting solution.

\section{Influence of organic matter}

Essential clove oil at $0.4 \%$ at $21{ }^{\circ} \mathrm{C}$ was the condition chosen to test the effect of the organic matter on the antibacterial activity. Assays were performed with Escherichia coli and Staphylococcus aureus as a representative scenario of a Gram positive and a gram negative response. The following organic substances were tested: $10 \%$ sterile rabbit serum $(\mathrm{v} / \mathrm{v})$, $1 \%$ brewers' yeast $(\mathrm{g} / \mathrm{v})$, and bovine serum albumin $(\mathrm{g} / \mathrm{v}), 10 \%$ in distilled water.

\section{Statistical Analysis}

The linear regression of death was performed with 
Microsoft Office Excel program. For linearity test the GraphPad Instat program (Graph Pad Software Inc., San Diego, USA) was used.

\section{RESULTS}

The results of the survivors log have been adjusted as to time, by linear regression. The values of death rate constant for each temperature and concentration are shown in Table 1. According to their inactivation rate $(\mathrm{k})$, bacterial sensitivity to clove essential oil at $21^{\circ} \mathrm{C}$ was 1.514 (Escherichia coli) > 1.334 (Pseudomonas aeruginosa) > Staphylococcus aureus (0.995).

Table 1. Kinetic parameters of bactericidal reaction.

\begin{tabular}{|c|c|c|c|}
\hline Microorganism & $\log k$ & $\mathbf{r}^{2}$ & $\mathbf{n}$ \\
\hline \multicolumn{4}{|l|}{ Escherichia coli } \\
\hline $0.4 \%-21^{\circ} \mathrm{C} *$ & 1.514 & 0.96 & 1.29 \\
\hline $0.2 \%-21^{\circ} \mathrm{C}$ & 0.620 & 0.96 & \\
\hline $0.4 \%-37^{\circ} \mathrm{C}$ & 4.425 & 0.91 & \\
\hline \multicolumn{4}{|c|}{ Pseudomonas aeruginosa } \\
\hline $0.4 \%-21^{\circ} \mathrm{C}$ & 1.334 & 0.96 & 1.04 \\
\hline $0.2 \%-21^{\circ} \mathrm{C}$ & 0.642 & 0.95 & \\
\hline $0.4 \%-37^{\circ} \mathrm{C}$ & 3.827 & 0.98 & \\
\hline \multicolumn{4}{|c|}{ Staphylococcus aureus } \\
\hline $0.4 \%-21^{\circ} \mathrm{C}$ & 0.995 & 0.95 & 0.22 \\
\hline $0.2 \%-21^{\circ} \mathrm{C}$ & 0.971 & 0.91 & \\
\hline $0.4 \%-37^{\circ} \mathrm{C}$ & 2.050 & 0.84 & \\
\hline
\end{tabular}

Figure 1 shows the effect of clove oil concentration $(0.2$ and $0.4 \% \mathrm{v} / \mathrm{v}$ ) on the survival of the three bacterial species. The concentration coefficient $(\mathrm{n})$ has been calculated as:

$$
\mathrm{n}=\log \mathrm{t}_{2} / \mathrm{t}_{1} / \log \mathrm{c}_{1} / \mathrm{c}_{2}
$$

where, $t_{1}$ and $t_{2}$ were the necessary times for a $99.9 \%$ reduction in the number of survivors with a $\mathrm{c}_{1}$ and $\mathrm{c}_{2}$ disinfectant concentration, respectively.
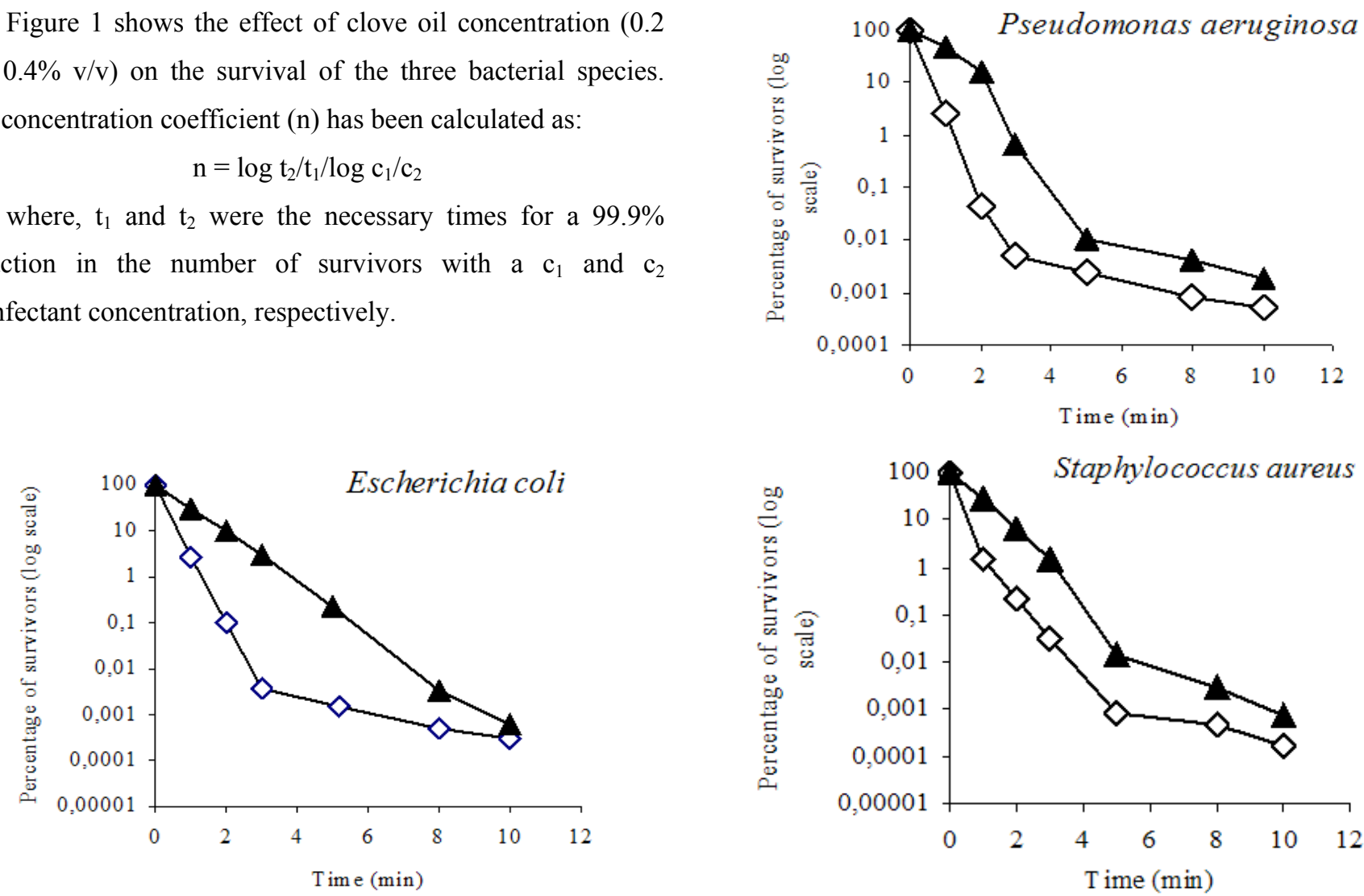

Figure 1. Kinetic of bacterial inactivation by essential clove oil at two concentrations. $(\diamond)$ essential clove oil at $0.4 \%-21^{\circ} \mathrm{C}$;

( $\Delta$ ) essential clove oil at $0.2 \%-21^{\circ} \mathrm{C}$. 
Figure 2 shows the effect of temperature $\left(21^{\circ}\right.$ and $\left.37^{\circ} \mathrm{C}\right)$ on the survival of bacterial species. The relationship with the death constant at two different temperatures shows an approximately linear correlation (14). For the inactivation of an organism with the same chemical agent and concentration, the ratio of time required to achieve the same level of inactivation as the temperature increased by $1^{\circ} \mathrm{C}$ is referred to as the $\mathrm{Q}_{1}$ value. This factor plays a highly variable role from one compound to another. For the same product, the temperature coefficient varies depending on the microorganism involved, but does not influence the concentration of the product. The temperature coefficients $\left(\mathrm{Q}_{1}\right)$ of essential clove for E. coli, $S$. aureus and $P$. aeruginosa were 1.07, 1.04 and 1.07 respectively.

Figure 3 show that adding organic matter to the disinfecting solution does not compromise antimicrobial activity. In the case of Staphylococcus aureus, albumin shows the greatest interference, as they needed 10 minutes to reach the reduction of $5 \log$ cycles in the bacterial population $(3 \mathrm{~min}$ are required in the absence of organic matter).
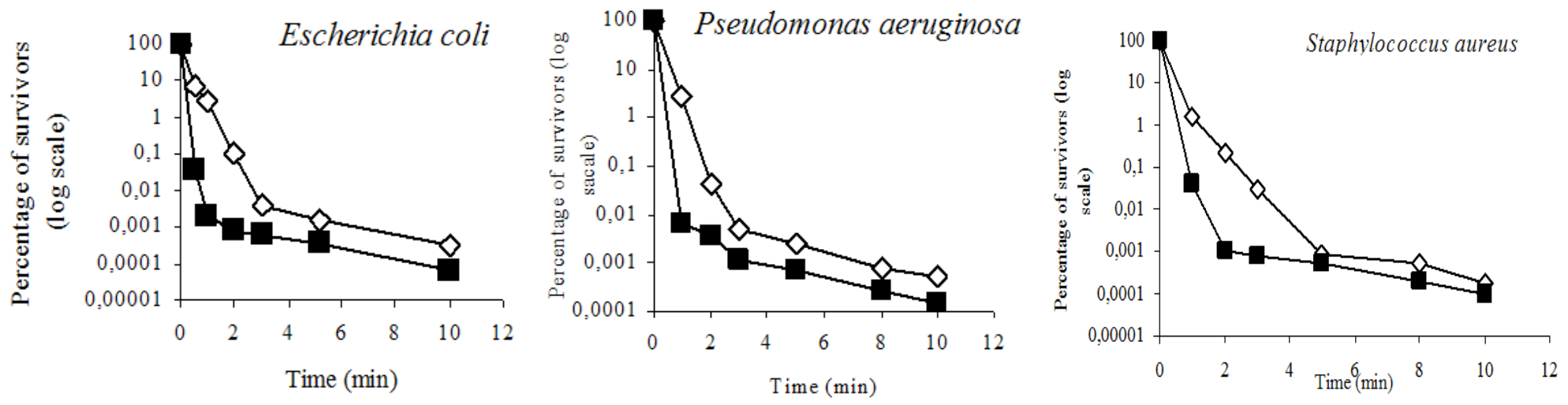

Figure 2. Kinetic of bacterial inactivation by essential clove oil at two temperatures 21 and $37^{\circ} \mathrm{C}$. $(\diamond)$ essential clove oil at $0.4 \%-21^{\circ} \mathrm{C}$;

(匹) essential clove oil at $0.4 \%-37^{\circ} \mathrm{C}$.
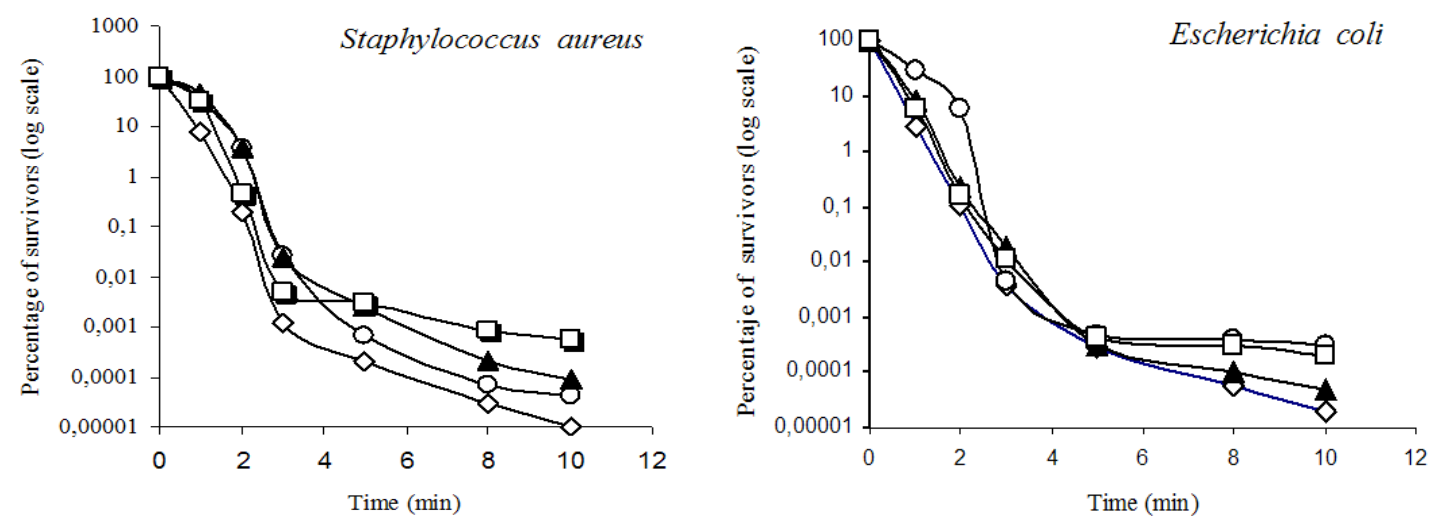

Figure 3. Influence of organic matter on bactericidal effect of clove oil. $(\diamond)$ absence of organic matter; ( $(\circ)$ serum $10 \%$; ( $\boldsymbol{\Delta})$ bakers' yeast $1 \%$; ( $\square)$ BSA $1 \%$ 


\section{DISCUSSION}

The inactivation curves presented biphasic kinetics, although the curve for Escherichia coli in the presence of $0.2 \%$ oil concentration at $21^{\circ} \mathrm{C}$ doesn't follow this pattern. A fast reduction in the viable count was detected during the first 3 to 5 minutes afterward the count remained constant. This behavior has been attributed to phenotypic and /or genotypic heterogeneity (16). Escherichia coli demonstrated a marked sensitivity showing a $6.72 \log$ decrease.

The concentration exponent quantifies the dilution effect in the antimicrobial activity $(14,8)$. The results obtained showed in Table 1 demonstrated a value of $n=0.22$ for Staphylococcus aureus and $\mathrm{n}=1.29$ for E. coli. Thus, halving the concentration will increase the time 1 - fold to reach the same end point against Staphylococcus aureus, while against Escherichia coli it will increase 4 times.

The inactivation kinetics depends on the temperature. Those results show that bacteria inactivation was more effective at a higher temperature $\left(37^{\circ} \mathrm{C}\right)$, thus the temperature coefficient calculation shows that at $37^{\circ} \mathrm{C}$ the activity is 18 to 19 times higher than a $21^{\circ} \mathrm{C}$, depending on the microorganism. This activity increase must be considered in the application of clove essential oil as antiseptic.

Any increase in temperature is linked to increased sensitivity due to the fact that membrane permeability of small molecules is due in part to the fluidity of the lipid layer. Gil and Suisted (10) have shown that the temperature modifies cell permeability which affects the proportion of unsaturated fatty acids. When permeability increases protection against a germicidal agent entry is reduced so clove essential oil can be dissolved in the membrane and accumulate with consequent damage to the membrane. The results observed with the bacterial strains suggest that there is a direct relationship between the damage caused through a membrane and cell death (2). At bactericidal concentrations the primary mechanism of action of eugenol is disruption of the cytoplasmic membrane, which increases its non-specific permeability (9).
The results show that organic matter reduces antibacterial activity, although it maintains its bactericidal efficacy: indeed, at $10 \mathrm{~min}$, the bacterial population was reduced by 5 logarithmic orders in the presence of albumin. It can be noted that the reduction degree of antimicrobial activity of the different types of assayed substances varies from one microorganism to another

It has already been shown in other studies $(5,11)$ that reduction of antimicrobial activity by organic matter shows variations between bacterial species. This variation was related with the structure cell wall, which shows significant differences in constitution and, consequently, differences in the capacity of combination with organic material and thus prevention of bactericidal capacity. Also, the interaction between antimicrobial agents and organic matter can result in a form less easily absorbed by different microorganisms.

In addition, the results obtained suggest that the characteristics of organic substances play an important role in the bactericide agent inactivation; this can be explained by the chemical composition of the interfering substance, high concentrations of proteins can cause significant interference with bactericidal solution activity (20). Different authors have explained that such differences within the interference degree could be found in both solubility and protein content of the different types of organic matter $(11,7)$. Even when dealing with different organic substances like serum, serum bovine albumin and brewers' yeast, clove essential oil maintains its bactericide capacity, and an increased interference was found with serum bovine albumin than whit brewers" yeast.

Clove essential oil can be considered as a potential antimicrobial agent for external use because it is not markedly inactivated by dilution or affected by organic matter. The design of clinical trials will determine its effectiveness in medical and dental practice.

\section{REFERENCES}

1. Briozzo, J.; Nuñez, L.; Chirife, J.; Herzage, L.; D’ Aquino, M. (1989). 
Antimicrobial activity of clove oil dispersed in concentrated sugar solution. J. Appl. Bacteriol. 66, 69-77.

2. Broxton, P.; Woodcock, P.M.; Gilbert, P.A. (1983). Study of the antibacterial activity some polyhexamethylene biguanides towards Escherichia coli ATCC8739. J. Appl. Bacteriol. 54, 345-353

3. Burt, S. (2004). Essential oils: their antibacterial properties and potencial applications in foods - a review. Int. J. Food Microbiol. 94, 223-253.

4. Chaib, K.; Hajlaoui, H.; Zmantar, T.; Kahla-Nakbi, A.B.; Rouabhia, M.; Mahdouani, K.; Bakhouf, A. (2007). The chemical composition and biological activity of clove essential oil, Eugenia caryophyllata (Syzigium aromaticum L. Myrtaceae): a short review. Phythoter. Res. 21, 501-506.

5. D’Aquino, M.; Nuñez, L. (1997). Influencia de la materia orgánica sobre la acción de desinfectantes. Rev. Arg. Infectol. 10, 3-9.

6. Dorman, H.J.D.; Deans, S.G. (2000). Antimicrobial agents from plants: antibacterial activity of plant volatile oils. J. Appl. Microbiol. 88, 308316.

7. Gélinas, P.; Goulet, J. (1983). Neutralization of the activity of eight disinfectants by organic matter. J. Appl. Bacteriol. 54, 243-247.

8. Gilbert, P.; Das, J.R.; Jones, M.V.; Allison, D.G. (2001). Assessment of resistance towards biocides following the attachment of micro-organisms to, and growth on, surfaces. J. Appl. Microbiol. 91, 248-254.

9. Gill, A.O.; Holley, R.A. (2006). Disruption of Escherichia coli, Listeria monocytogenes and Lactobacillus sakei cellular membranes by plant oil aromatics. Int. J. Food Microbiol. 108 1-9.

10. Gill, C.O.; Suisted, J.R. (1978). The effect of temperature and growth rate on the proportion of unsaturated fatty acids in bacterial lipids. $J$. Gen. Microbiol. 104, 31-36.

11. Hammer, K.A.; Carson, C.F.; Riley, T.V. (1999). Influence of organic matter, cations and surfactants on the antimicrobial activity of Melaleuca alternifolia (tea tree) oil in vitro. J. Appl. Microbiol. 86, 446-452.

12. Holley, R.A., Patel, D. (2005). Improvement of shelf-life and safety of perishable foods by plant essential oils and smoke antimicrobials. Food Microbiol. 22, 273-292.

13. Huang, Y.; Ho, S.H.; Lee, H.C.; Yap, Y.L. (2002). Insecticidal properties of eugenol, isoeugenol and methyleugenol and their effects on nutrition of Sitophilus zeamais Motsch. J. Stored Prod. Research 38, 403-412.

14. Jordan, R.C.; Jacobs, S.E. (1994). Studies on the dynamics of disinfection. VII The reaction between phenol and E. coli. The effect of $\mathrm{T}$ on the usually accepted concentration exponent and the calculation of a more satisfactory exponent based on theoretical considerations. J. Hyg. 44, 421-429.
15. Lee, K.G.; Shibamoto, T. (2001). Antioxidant property of aroma extract isolated from clove buds. Food Chem. 74, 443-448.

16. L' Haridon, R.; Cerf, O. (1998). La desinfection et l'antisepsie: proposition d'un mode de raisonnement tenent compte des cinetiques d'inactivation des microorganismes. Rev. Inst. Pasteur Lyon 11, 445-456.

17. Matan, N.; Rimkeeree, H.; Mawson, A.J.; Chompreeda, P.; Haruthaithanasan, V.;Parker, M. (2006). Antimicrobial activity of cinnamon and clove oils under modified atmosphere conditions. J. Food Microbiol. 107, 180-185.

18. Meeker, H.G.; Linke, H.A.B. (1988). The antibacterial action of eugenol, thyme oil, and related essential oils used in dentistry. Compend. Contin. Educ. Dent. 9, 33-40.

19. Nuñez, L.; D'Aquino, M.; Chirife, J. (2001). Antifungal properties of clove oil (Eugenia caryophylata) in sugar solution. Braz. J. Microbiol. $32,123-126$.

20. Paz, L.M.; Gallego Dúalgues, M.V.; Hanashiro, A.; D’Aquino, M.; Santini, P. (1993). Antimicrobial effect of chlorine on Yersinia enterocolítica. J. Appl. Bacteriol. 75, 220-225.

21. Prabuseenivasan, S.; Jayakumar, M.; Ignacimuthu, S. (2006). In vitro antibacterial activity of some plant essential oils. BM Complementary Altern. Med. 6, 39.

22. Shapiro, S.; Meier, A.; Guggenheim, B. (1994). The antimicrobial activity of essential oils and essential oil components towards oral bacteria. Oral Microbiol. Immunol. 9, 202-208.

23. Smith-Palmer, A.; Stewart, J.; Fyfe, L. (2001). The potential application of plant essential oils as natural food preservatives in soft cheese. Food Microbiol. 18, 463-470.

24. Tajkarimi, M.M.; Ibrahim, S.A.; Cliver, D.O. (2010). Antimicrobial herb and spice compounds in food. Food Control 21, 1199-121.

25. Thrash, R.J.; Reich, R.R. (2001). Physical Factors Influencing the activity of antimicrobial agents. In: Seymour S. Block (Eds). Disinfection, Sterilization, and Preservation. Lippincott Williams Wilkins, pp. 57-64.

26. Walsh, S.E.; Maillard, J.-Y.; Russell, A.D.; Catrenich, C.E.; Charbonneau, D.L.; Bartola, R.G. (2003). Activity and mechanisms of action of selected biocidal agents on Gram-positive and -negative bacteria. J. Appl. Microbiol., 94, 240-247.

27. Weavers, L.K.; Wickramanayake, G.B. (2001). Kinetic of the Inactivation of Microorganisms. In: Seymour S. Block. (Eds), Disinfection, Sterilization, and Preservation. Lippincott Williams Wilkins, pp. 65-71. 